\title{
Extractability and Intracellular Localisation of Urea Cycle Enzymes from Rat Liver
}

\author{
By K.-P. Maier, Ch. Helbig, G. Hoppe-Seyler, H. Talke, J. Fröhlich, P. Schollmeyer and W. Gerok' ', \\ Department of Internal Medicine, University of Freiburg
}

(Eingegangen am 31. Dezember 1973/4. Juli 1974)

\begin{abstract}
1. Urea cycle enzymes and ornithine ketoacid transaminase were extracted from rat liver using various buffer systems and different procedures for the mechanical disintegration of the cells. Of the buffers tested, phosphate and glutathione gave optimal results, whereas significant differences were found when other extracting media were used: activities of ornithine ketoacid transaminase and ornithine carbamyl transferase were significantly decreased in triethanolamine- and in tris-[hydroxymethyl]-aminomethane (tris)-buffer when compared with phosphate. Arginase activity remains unchanged in phosphate and in tris-buffer, but it decreased significantly in triethanolamine-buffer. With the exception of ornithine ketoacid transaminase, no significant increase of enzyme activities were found when livers were extracted with $0.1 \%$ cetylammonium bromide and distilled water respectively.
\end{abstract}

Carbamylphosphate synthetase from rat liver was inactive in the presence of phosphate ions as was ornithine ketoacid transaminase when glutathione $(1 \mathrm{mmol} / 1 \mathrm{GSH})$ was added to the extracting medium. With the exception of carbamylphosphate synthetase, all other enzymes tested showed significantly higher activities in liver homogenates than in $100000 \mathrm{~g}$ supernatants.

2. Optimal extraction of urea cycle enzymes from small specimens (e. g. liver biopsies) could be achieved by disintegrating the tissue in an micro all-glass homogenizer, followed by ultrasonic treatment. The use of cetylammonium bromide and the reextraction of bioptic specimens could be avoided. In contrast, larger tissue samples (500 mg and more) must be reextracted for the complete elution of urea cycle enzymes.

3. Urea cycle enzymes and ornithine ketoacid transaminase were differentiated according to the intracellular localisation by the method of fractional tissue extraction. It could be demonstrated that ornithine ketoacid transaminase, carbamylphosphate synthetase and ornithine carbamyl transferase were of mitochondrial origin, whereas argininosuccinate lyase activity was found exclusively in the extramitochondrial cell compartment. Arginase activity could be measured mainly extramitochondrially, most probably bound to subcellular structures. However it could not be excluded that at least a small amount of this enzyme was of mitochondrial origin.

1. Harnstoffcyklusenzyme und Ornithin-Ketosäure-Transaminase wurden unter Verwendung unterschiedlicher Extraktionspuffer und unterschiedlicher Methoden zur mechanischen Zelldesintegration aus Rattenlebern extrahiert. Optimale Ausbeuten wurden mit Phosphat- und Glutathionpuffern erzielt, während bei Verwendung von Triäthanolamin- und Tris-[hydroxymethyl]-aminomethan(Tris)-Puffer die Aktivitäten der Ornithin-Ketosäure-Transaminase und der Ornithin-Carbamyltransferase signifikant niedriger lagen als im Phosphatmedium. Die Aktivität der Arginase war in Phosphat- und in Trispuffer unverändert, hingegen in Triäthanolamin signifikant erniedrigt. Abgesehen von der Aktivität der Ornithin-Ketosäure-Transaminase, fand sich kein Enzymanstieg, wenn die Extraktion in 0,1\% Cetylammoniumbromid oder in destilliertem Wasser erfolgte.

Rattenleber-Carbamylphosphatsynthetase war in Gegenwart von Phsophationen inaktiv, ebenso wie die Ornithin-Ketosäure-Transaminase bei Zugabe von reduziertem Glutathion ( $1 \mathrm{mmol} / 1 \mathrm{GSH})$ zum Extraktionsmedium.

Abgesehen von der Carbamylphosphatsynthetase, zeigten alle von uns getesteten Enzyme signifikant höhere Aktivitäten in Leberhomogenaten verglichen mit den Aktivitäten in $100000 \mathrm{~g}$-Überständen.

2. Optimale Ausbeuten von Enzymaktivitäten des Harnstoffcyklus aus kleinen Gewebsproben (z. B. Leberpunktionszylinder) ergaben sich durch die Kombination von Gewebshomogenisation in einem Mikro-Glas-Glas-Homogenisator, gefolgt von Ultraschallbehandlung des Homogenates. Die Verwendung von Cetylammoniumbromid bzw. Reextraktion des Gewebes kann entfallen. Größere Gewebsproben ( $500 \mathrm{mg}$ Leber und mehr) müssen jedoch zur vollständigen Extraktion der Harnstoffcyklusenzyme nachextrahiert werden.

3. Harnstoffcyklusenzyme und Ornithin-Ketosäure-Transaminase wurden differenziert hinsichtlich ihrer intrazellulären Lokalisation in der Rattenleber mittels der Methode der fraktionierten Zellextraktion. Hierbei ergab sich, daß die Aktivitäten der Ornithin-Ketosäure-Transaminase, der Ornithin-Carbamyltransferase und der Carbamylphosphatsynthetase ausschließlich dem intramitochondrialen, diejenige der Argininosuccinatlyase ausschließlich dem extramitochondrialen Zellkompartiment zugeordnet werden konnte.

Auch der größte Anteil der Arginaseaktivität konnte, höchstwahrscheinliçh strukturgebunden, im Cytoplasma der Leberzelle nachgewiesen werden. Es kann jedoch nicht ausgeschlossen werden, daß ein Teil der Gesamtaktivität der Arginase in den Mitochondrien selbst vorkommt.

Isolated defects of urea cycle enzymes causing severe metabolic disorders in children have been known for several years $(1,2)$. Increasing interest has recently . been focused on patients suffering from various liver diseases. Decreased activities of arginase and of argi- ninosuccinate synthetase were found in endogenous liver coma (3). Haag et al (4) demonstrated that patients suffering from chronic active hepatitis showed significant decrease of argininosuccinate synthetase activity. Finally, Inamasu et al (5) emphasize the close 
relationship between intracellular localisation of urea cycle enzymes and exogenous damage of the liver. After $\mathrm{CCl}_{4}$ intoxication, only mitochondrially localized enzymes decreased, whereas the activities of the cytoplasmatic enzymes of the Krebs-Henseleit cycle remained unchanged.

Investigations of urea cycle enzymes in man were performed mainly in fibroblast cell cultures or in liver specimens obtained intraoperatively. Extraction procedures were based preferably on the method of Brown et al (6), who homogenized liver samples in $0.1 \%$ cetylammonium bromide. After homogenization in an all-glass homogenizor and reextraction of the sedimental fraction, urea cycle enzymes were determined in the combined supernatants. The application of this procedure is restricted to relatively large amounts of tissue. However, it is not suitable for tissue specimens obtained by liver biopsy. Furthermore, cetylammonium bromide may considerably inhibit enzyme activity (7).

In this study the effect of different homogenization media and extraction procedures on the extractability of urea cycle enzymes from rat liver were investigated in order to establish a standardized method of extracting these enzymes from very small tissue samples (20-30 mg wet weight). Total activities of urea cycle enzymes and ornithine ketoacid transaminase were determined as well as the total amount of enzyme activities extractable from the cytoplasmatic and mitochondrial cell compartment respectively. Finally, the influence of deep freezing and storage on the activities of urea cycle enzymes were investigated.

\section{Materials and Methods}

\section{Animals}

Female Wistar rats (170-180 g, Fa. Ivanovas, Kieslegg, Allgäu) were used in all experiments. The animals were fed with a standard diet (Altromin) and had free access to food and water. The rats were killed by decapitation under ether anesthèsia. The livers were removed immediately and homogenized (see below) or deep frozen at $-75^{\circ} \mathrm{C}$.

\section{Reagents}

Chemical reagents, ultrapure, were purchased from E. Merck, Darmstadt. The barium salt of argininosuccinic acid and cetylammoniumbromide were obtained from Serva, Heidelberg. The barium salt was converted into the sodium salt. Substrates, enzymes and coenzymes were from Boehringer, Mannheim. All solutions were prepared with quartz-distilled water. Bovine serum albumin was from $\mathrm{Fa}$. Behringwerke, Marburg.

\section{Enzyme extraction}

All experiments were performed at $4{ }^{\circ} \mathrm{C}$.

Minced rat liver was homogenized in a 19-fold volume $(w / v)$ of the appropriate homogenisation medium in an all-glass or teflon-glass Potter-Elvehjem micro-homogenizor (volume $3 \mathrm{ml}$ ). The homogenates were disintegrated by ultrasonic treatment (Branson-Instruments, Philadelphia, USA, microequipement, sonifier B-12, output 40 watts) for $30 \mathrm{~s}$ ( $30 \mathrm{mg}$-specimens) and $100 \mathrm{~s}$ respectively (500 $\mathrm{mg}$-specimens during fractional tissue extraction).

\section{Enzyme tests}

Lactate dehydrogenase (EC 1.1.1.27) and aspartate aminotransferase (EC 2.6.1.10) were determined according to Bücher et al (8). Glutamate dehydrogenase (EC 1.4.1.3) was determined as described previously (9). Ornithine carbamyl transferase (EC 2.1.3.3) was measured according to Schimke et al. (10). Rat liver homogenate was incubated in $67 \mathrm{mmol} / 1$ phosphate, pH 7.0 as described by Ceriotti et al (11). Carbamylphosphate synthetase (EC 2.7.2.2) was tested according to Brown et al (6). Citrulline was determined colorimetrically by the diphenyloxime reaction at $492 \mathrm{~nm}$. Arginase (EC 3.5.3.1) and argininosuccinate lyase (EC 4.3.2.1) were tested according to Schimke et al (10), ornithine ketoacid transaminase

(EC. 2.6.1.13) according to Peraino et al (12). All enzymatic tests were performed in the micro-scale (finale volumes $0.25-0.5 \mathrm{ml}$ ). All tests were done in duplicate or as proportional tests. Enzyme activities are expressed as U/g fresh weight or $\mathrm{U} / \mathrm{mg}$ protein.

Protein was determined with the biuret method (13) using bovine serum albumin as a standard.

\section{Fractional tissue extraction}

Fractional tissue extraction was performed according to Pette (14). Activities of cytoplasmic and mitochondrial enzymes were determined in the $100000 \mathrm{~g}$ supernatants.

Statistical analy ses

were performed by Student's t-test.

\section{Results}

Figure 1 shows enzyme activities obtained by extracting one and the same tissue sample with different homogenization procedures. Enzyme activities are given in per cent of total extractable activity (referred to $\mathrm{U} / \mathrm{mg}$

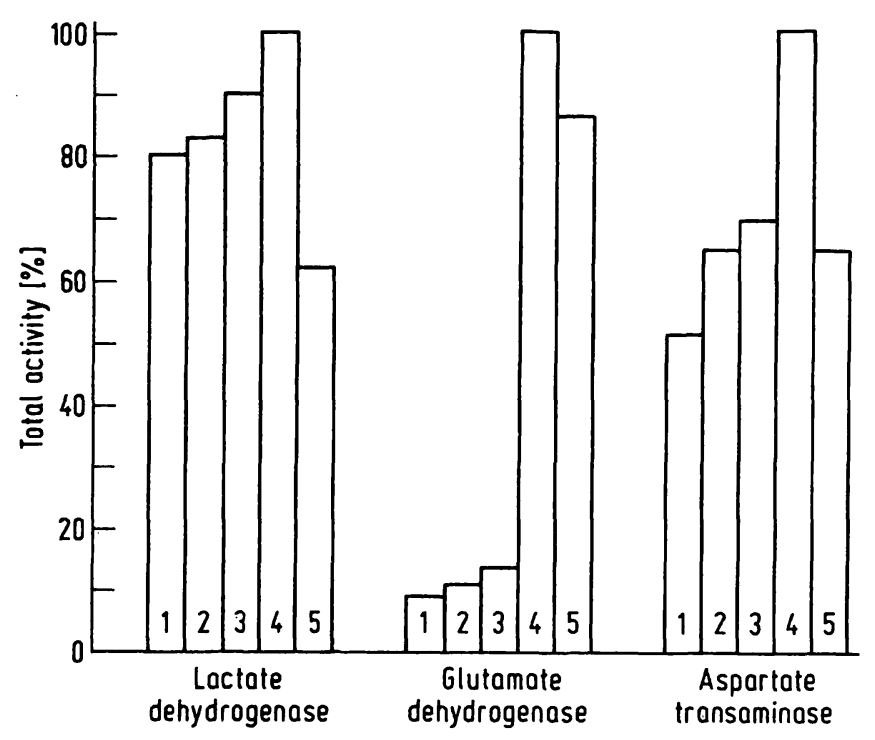

Fig. 1. Minced rat liver was homogenized in $0.1 \mathrm{~mol} / 1$ phosphate, pH 7.4 as follows:

1) all-glass homogenizor

2) teflon-glass-homogenizor

3) all-glass and teflon-glass-homogenizor

4) as stated in 3) plus ultrasonic treatment $(10 \times 10 \mathrm{~s})$

5) ultrasonic treatment only (without prior homogenisation).

Enzyme activities were determined in the homogenates. Enzyme activities are listed as relative percentages of total enzyme activity $(=100 \%$ ), referred to $\mathrm{U} / \mathrm{mg}$ protein. 
protein). The results indicate that cytoplasmic enzymes are nearly totally extractable with an all-glass or with a teflon-glass homogenizer. In contrast, using the same procedure, only $10 \%$ of the enzymes localized within the mitochondria can be extracted (see Fig. 1., glutamate dehydrogenase, number 1-3). As for aspartate aminotransferase, an intracellularly "multilocated" enzyme, a marked increase of enzyme activity could be noticed by combining two procedures of tissue extraction (see Fig. 1, aspartate aminotransferase, number 1 and 3). Irrespective of the intracellular localisation of the enzymes, a combination of both procedures, i. e. homogenisation and ultrasonic treatment of liver homogenates, always resulted in the highest yield of extractable enzyme activity.

\section{The effect of different homogenisation media}

The results obtained with different homogenisation media are shown in Table 1. In general, except for carbamylphosphate synthetase, enzyme activities were higher when the extraction was performed with $0.1 \%$ cetylammonium bromide than with distilled water only. Apart from ornithine ketoacid transaminase, however, the increase of enzyme activities showed no significance in both groups.

Table 2 summarizes the results obtained with different buffer systems. It can be seen that ornithine ketoacid transaminase-activity is significantly higher in phosphate buffer than in triethanolamine or tris buffer. Similar findings can be demonstrated for ornithine carbamyl transferase. Activities of arginase did not differ in phosphate and in tris buffer. In triethanolamine-buffer, however, enzyme activity was significantly $(p<0.005)$ decreased. Argininosuccinate lyase activity in phosphate and in tris buffer were nearly identical'. The marked decrease of enzyme activity in triethanolamine buffer was statistically not significant. Carbamylphosphate synthetase, inactive in the presence of phosphate ions, was slightly elevated in tris when compared with triethanolamine as the extraction medium.

Total activities of urea cycle enzymes in $100000 \mathrm{~g}$ supernatants and in homogenates of rat liver are listed in Table 3. With the exception of carbamylphosphate synthetase, activities of all other enzymes are significantly higher in homogenates than in supernatants. Furthermore it can be seen (see Table 3) that the use of $1 \mathrm{mmol} / 1 \mathrm{GSH}$ as the extraction medium is not associated with an activation of the enzymes of the Krebs-Henseleit cycle.

\section{Reextraction of rat liver according to size}

Reextraction of $500 \mathrm{mg}$ of rat liver with phosphate buffer showed that considerable amounts of urea cycle enzymes can be extracted from the sedimental fraction,

Tab. 1. Activities of urea cycle enzymes extracted with distilled water and $0.1 \%$ cetylammonium bromide respectively (homogenization according to procedure 4 (see Fig. 1.)). Means \pm S.D. $n=4$. Enzymes are tested in the $100000 \mathrm{~g} / 30$ min supernatants. $\mathrm{U} /$ wet weight are listed.

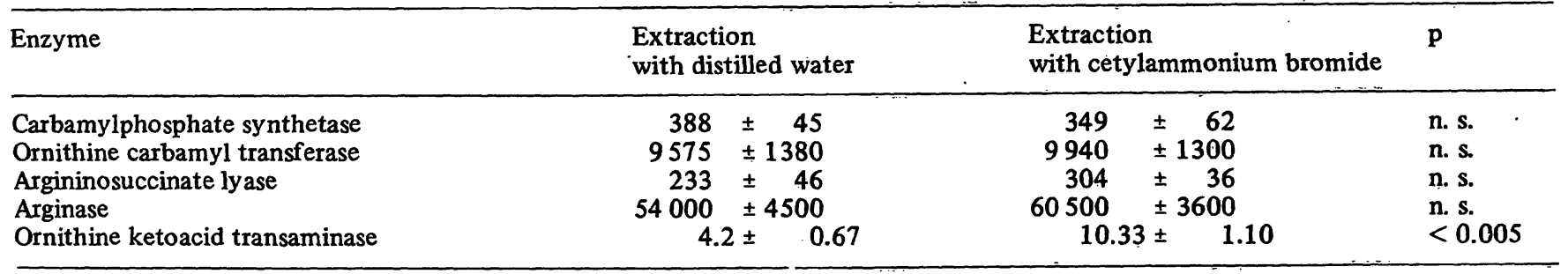

Tab. 2. Activities of urea cycle enzymes in rat liver extracted with various buffers. Rat liver $(n=4)$ were homogenized in a PotterElvehjem all-glass homogenizer. After ultrasonic treatment of the homogenate, enzyme activities (U/g wet weight) were determined in the $100000 \mathrm{~g} / 30 \mathrm{~min}$ supernatants. Means $\pm \mathrm{S}$. D. are listed.

\begin{tabular}{|c|c|c|c|c|c|}
\hline & $\begin{array}{l}\text { Ornithine } \\
\text { ketoacid } \\
\text { transaminase }\end{array}$ & $\begin{array}{l}\text { Ornithine } \\
\text { carbamyl } \\
\text { transferase }\end{array}$ & $\begin{array}{l}\text { Carbamyl- } \\
\text { phosphate } \\
\text { synthetase }\end{array}$ & Arginase & $\begin{array}{l}\text { Arginino- } \\
\text { succinate } \\
\text { lyase }\end{array}$ \\
\hline $\begin{array}{l}0.1 \mathrm{~mol} / 1 \text { phosphate, } \mathrm{pH} 7.4 \\
0.1 \mathrm{~mol} / 1 \text { Triethanolamine, } \mathrm{pH} 7.4 \\
0.1 \mathrm{~mol} / 1 \text { Tris, } \mathrm{pH} 7.4\end{array}$ & $\begin{aligned} 48.9 & \pm 7.7 \\
18.19 & \pm 2.03 \\
9.90 & \pm 3.9\end{aligned}$ & $\begin{array}{l}9970 \pm 400 \\
1800 \pm 270 \\
1800 \pm 350\end{array}$ & $\begin{array}{l}\overline{262} \pm 35 \\
332 \pm 30\end{array}$ & $\begin{array}{l}63000 \pm 2300 \\
24300 \pm 6050 \\
56800 \pm 6300\end{array}$ & $\begin{array}{l}399 \pm 106 \\
206 \pm 100 \\
442 \pm 117\end{array}$ \\
\hline
\end{tabular}

Statistical analysis of the data of table 2 (p-values are listed with regard to buffers):

Ornithine ketoacid transaminase: phosphate/Triethanolamine: $<0.001$ Ornithine carbamyl transferase: phosphate/Triethanolämine: $<0.001$ Carbamylphosphate synthetase: Arginase: Argininosuccinate lyase:
phosphate/Triethanolamine: -

phosphate/Triethanolamine: $<0.001$ phosphate/Triethanolamine: $<0.05$
phosphate/Tris: $<0.001$ phosphate/Tris: $<0.001$ phosphate/Tris: phosphate/Tris: 'n. s. phosphate/Tris: n. s.
Triethanolamine/Tris: $<0.02$

Triethanolamine/Tris: $\mathbf{n}$. s.

Triethänolamine/Tris: $<0.02$

Triethanolamine/Tris: $<0.001$

Triethanolamine/Tris: $<0.02$ 
Tab. 3. Activities of urea cycle enzymes in rat liver homogenates and in $100000 \mathrm{~g} / 30 \mathrm{~min}$-supernatants. Homogenisation medium: $1 \mathrm{mmol} / 1 \mathrm{GSH}, \mathrm{pH}$ 7.0. Enzyme activities are expressed in U/g wet weight. Means \pm S.D. $n=4$. Ornithine ketoacid transaminase showed no activity in the presence of GSH.

\begin{tabular}{lrrr}
\hline Enzyme & Supernatants & Homogenates & p \\
\hline Carbamylphosphate synthetase & $338 \pm 58$ & $357 \pm 68$ & n.s \\
Ornithine carbamyltransferase & $6600 \pm 1100$ & $10000 \pm 1770$ & $<0.01$ \\
Argininosuccinate lyase & $347 \pm 24$ & $477 \pm 85$ & $<0.02$ \\
Arginase & $48800 \pm 1500$ & $56000 \pm 2750$ & $<0.001$ \\
\hline
\end{tabular}

as reported by Brown et al (6). In our experiments residual activities ranged from $5.5 \%$ ornithine carbamyl transferase $-22 \%$ argininosuccinate lyase of total enzyme activity in the pellet.

In contrast, reextraction can be avoided when very small tissue samples are used. Residual activities in bioptic specimens (30 mg) are markedly decreased. Only $2.5 \%$ of arginase, $4.8 \%$ of carbamylphosphate synthetase, $1.3 \%$ of ornithine carbamyl transferase, $0.6 \%$ of ornithine ketoacid transaminase and $7.1 \%$ of argininosuccinate lyase activity (enzyme activity in the homogenates $=100 \%$ ) were found in the pellets of small liver specimens.

\section{Stability of urea cycle enzymes}

Figure 2 shows changes of enzyme activity in deepfrozen rat liver, stored at $-75^{\circ} \mathrm{C}$. No significant decrease of enzyme activities could be noticed during

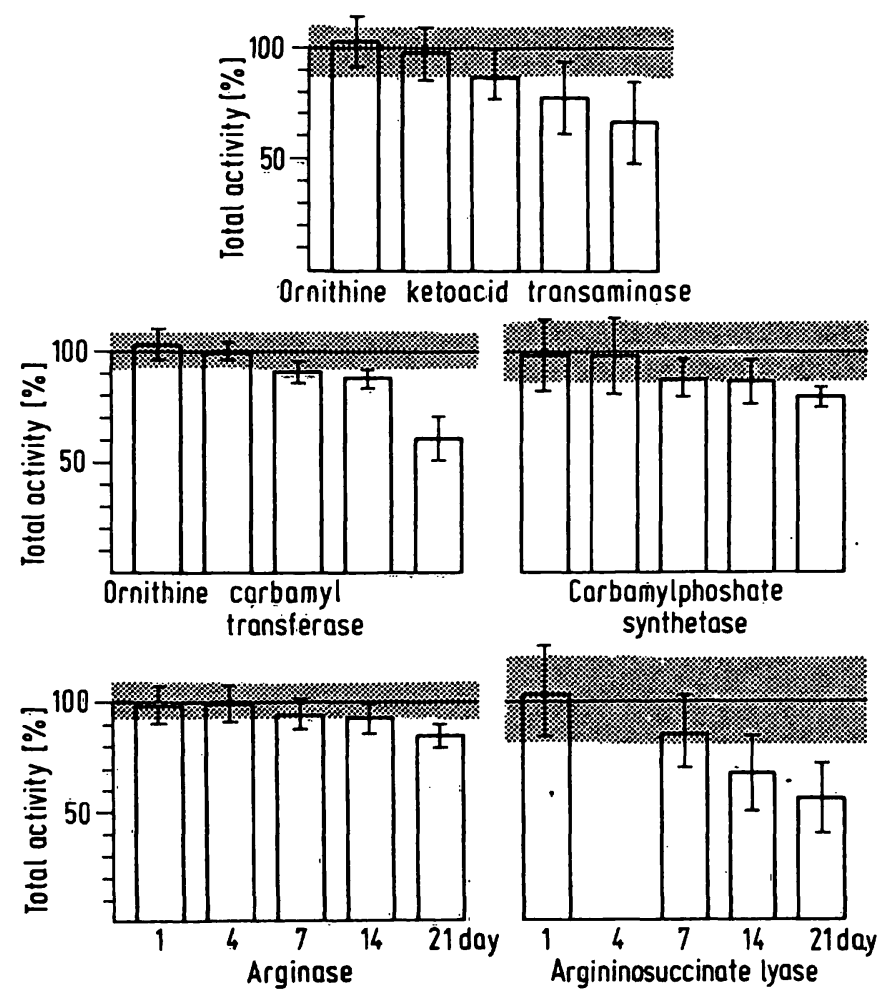

Fig. 2. Effect of storage at $-75^{\circ} \mathrm{C}$ upon enzyme activities of the Krebs-Henseleit cycle. Enzyme activities $(n=4)$ were determined at various intervals. Normal values (zero-time) are represented by horizontal bars. Means \pm S. D. are listed. a 14-day period. After this period, however, a continuous loss of enzyme activity could be demonstrated. The decrease of ornithine carbamyl transferase, ornithine ketoacid transaminase and argininosuccinate lyase activities is statistically significant, whereas activities of the other enzymes remained nearly unchanged.

\section{Intracellular localisation of urea cycle enzymes}

The results of fractional tissue extraction are shown in Figure 3. In these experiments lactate dehydrogenase was used as a cytoplasmatic, glutamate dehydrogenase as a mitochondrial "marker" enzyme. Intracellular distribution of both lactate dehydrogenase and glutamate dehydrogenase activities demonstrate that the cytoplasma was extracted almost completely before disintegration of the mitochondria, the latter beeing associated with the rise of glutamate dehydrogenase activity ( $\mathrm{S}_{4}-\mathrm{P}$ in Fig. 3.).

About $4 \%$ of total glutamate dehydrogenase activity can be demonstrated in the extramitochondrial cell compartment.

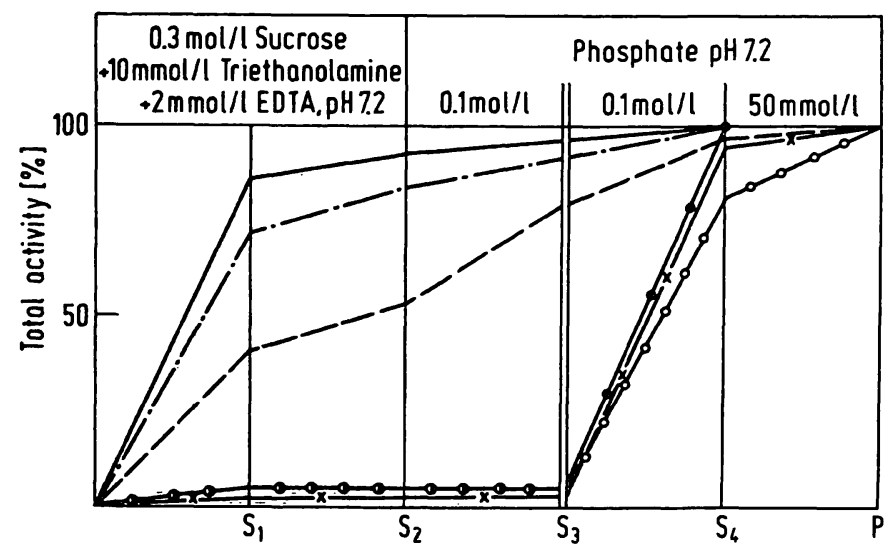

Fig. 3. Fractional tissue extraction of urea cycle enzymes from rat liver. Enzyme activities are given as relative amounts of total enzyme activity $(=100 \%)$. Enzyme tests were performed in the $100000 \mathrm{~g} / 30 \mathrm{~min}$ supernatants $\left(\mathrm{S}_{1}\right.$ $S_{4}$ ) and in the pellet fraction (P).S1-S $S_{3}$ represent the cytoplasmatic, $S_{4}$ and $P$ the mitochondrial cell compartment. Mean values of four experiments are listed. Percentages of enzyme activities are referred to $\mathrm{U} / \mathrm{g}$ wet weight.

Argininosuccinate lyase
- Lactate dehydrogenase
$-\quad$ Arginase
-0 Ornithine carbamyl transferase
- Glutamate dehydrogenase
O Ornithine ketoacid transaminase


Enzymes located in the mitochondrial matrix can be extracted with phosphate buffer of high ionic strength and with ultrasonic treatment $\left(\mathrm{S}_{4}\right)$, structurally bound enzymes can be determined in the homogenate of the sedimental fraction (P). It is evident from Figure 3 that argininosuccinate lyase is exclusively localized in the cytoplasm. Carbamylphosphate synthetase (not shown in Fig. 3), determined with a modification of the fractional tissue extraction method, shows the same behaviour during the extraction procedure as ornithine carbamyl transferase. $98 \%$ of total activity of both enzymes was of mitochondrial origin. Arginase shows an elution pattern typical for an enzyme located both in the cytoplasmatic and in the mitochondrial cell compartment. The greater part $(80 \%)$ of total enzyme activity can be determined in the supernatants of the cytosolic fractions $\left(S_{1}-S_{3}\right)$, while about $20 \%$ of total arginase activity is set free after disruption of the mitochondrial membrane.

\section{Discussion}

\section{Extraction of urea cycle enzymes from rat liver}

Our results indicate that the extractibilitly of rat liver enzymes varies greatly due to their different intracellular localisation and due to the type of the extraction procedure used. Optimal elution of both the cytoplasmatic and the mitochondrial enzyme activities can only be obtained by the combination of homogenisation and ultrasonic treatment of the homogenate. Furthermore, extractibility of urea cycle enzymes is influenced by the amount of tissue used. The method of combining two procedures of mechanical tissue disintegration shows optimal results only with very small tissue specimens, for instance from bioptic material, whereas reextraction is necessary when relatively large amounts of tissue $(500 \mathrm{mg}$ and more) have to be extracted.

Brown et al (6) emphasized that the use of cetylammonium bromide leads to a more complete extraction of urea cycle enzymes, far superior to all other extracting media. Our results, however, indicate that cetylammonium bromide-extraction was associated only with significantly increased activities of ornithine ketoacid transaminase, and slightly, but not significantly increased activities of ornithine carbamyl transferase when compared with enzyme activities extracted with distilled water. The increase of the other enzyme activities were statistically not significant. However, in other, detergent-free extracting media, a 5-fold increase of ornithine ketoacid transaminase activity could be demonstrated (see Table 2).

\section{Stability of urea cycle enzymes}

Only a few data are available on the activities of urea cycle enzymes in deep frozen tissues. Strecker (15) found no alteration of ornithine ketoacid transaminase activity in sucrose and phosphate homogenates of rat liver when stored at $-15^{\circ} \mathrm{C}$ for weeks. Under identical conditions, however, the activity of the soluble enzyme decreased more than 50 per cent within 6 days.

Jones et al (16) demonstrated that no decrease of carbamylphosphate synthetase activity from frog liver could be detected over a period of one year.

Our own data show that a marked decrease of some of the urea cycle enzymes occurs after a 14-day period at $-75^{\circ} \mathrm{C}$. For practical purpose it should be emphasized that urea cycle enzymes should be measured within this period to avoid misinterpretation of enzyme activities due to storage of the tissue specimens.

\section{Intracellular localisation of urea cycle enzymes}

Our findings of the intracellular localisation of arginino'succinate lyase and arginase in rat liver agree well with results published by Mora et al (17). Using differential centrifugation they localized all the argininosuccinate lyase and about 80 per cent of the arginase activity in the cytoplasm, whereas $20 \%$ of the arginase activity was bound to subcellular structures (17). Our results cannot exclude that at least a small amount of arginase activity in rat liver is of mitochondrial origin. With regard to the different amounts of arginase activity using different extracting media it can be concluded that this enzyme is attached to subcellular structures in rat liver. Indeed Mora et al (17) found about $40 \%$ of rat liver arginase to be bound to microsomal protein. Furthermore these authors noted that nearly half of the total activities of ornithine carbamyl transferase and of carbamylphosphate synthetase are of extramitochondrial origin. In contrast to this, our results indicate that both enzymes are exclusively located within the mitochondria. These findings are supported by differential centrifugation studies of Strecker (15) and with electron microscopic findings (18). These methods failed to demonstrate measurable amounts. of ornithine carbamyl transferase, ornithine ketoacid transaminase and carbamylphosphate synthetase extramitochondrially, results, which are in good agreement with our studies.

During fractional tissue extraction a small amount of mitochondrial enzymes can be found in the extramitochondrial space. Our studies on glutamate dehydrogenase activity demonstrated that this is due to mechanical damage of mitochondria during fractional tissue extraction (19). Therefore it seems reasonable to conclude that the same is true for ornithine carbamyl transferase, carbamylphosphate synthetase and ornithine ketoacid transaminase activities too.

Our study revealed that a standardized procedure of extracting urea cycle enzymes from liver specimens is mandatory if the misinterpretation of enzyme activities is to be avoided. 
It could be demonstrated that the method of fractional tissue extraction allows the differentiation of urea cycle enzymes according to their extramitochondrial and mitochondrial localisation respectively. Furthermore, reextraction studies showed that the combination of two extraction procedures allowed the elution of urea cycle enzymes nearly quantitatively from small tissue samples, e. g. bioptic specimens.

Marked differences in arginase and carbamylphosphate synthetase activities have been found in bioptic samples of patients with alcoholic hepatitis (20). It should be emphasized that fractional tissue extraction in the microscale (21), using liver biopsies, will enable us to establish patterns of enzyme activities in men under in vivo conditions (in preparation).

\section{Acknowledgement}

The skillful technical assistance of Miss $U$. Ehret is gratefully acknowledged.

Parts of this work will be presented as a doctoral thesis, at the Medical Faculty, University of Freiburg (Ch. Helbig).

This study was supported by the Deutsche Forschungsgemeinschaft, Bad Godesberg, (Ma 359/6).

\section{References}

1. Shive, L. \& Efron, M. L. (1972), in The Metabolic Basis of Inherited Disease (Stanbury, J. B., Wyngaarden, J. \& Frederickson, D. S. eds.) Mc. Graw Hill, New York, p. 374.

2. Colombo, J. P. (1972), Erg. Inn. Med. Kinderheilk. 31, 76-130.

3. Ugarte, G., Pino, M. L., Valenzuela, J. \& Lorca, F. (1963), Gastroenterology, 45, 182-188.

4. Haag, G., Holldorf, A. W. \& Gerok, W. (1972), Klin. Wochenschr. $50,887-888$.

5. Inamasu, Y., Sameshima, Y., Haghiara, S. \& Ibo, F. (1972), Acta Med. Univ. Kagoshima, 14, 63-69.

6. Brown, G. W. \& Cohen, P. P. (1959), J. Biol. Chem. 234, 1769-1774.

7. Marshall, M., Metzenberg, R. L. \& Cohen, P. P. (1958), J. Biol. Chem. 233, 102-111.

8. Bücher, T., Luh, W. \& Pette, D. (1964), in: Hoppe-SeylerThierfelder, Handbuch der Physiol. Chem. Analyse, 10th ed., Vol. VI/A, Springer-Verlag, Berlin, p. 292-339.

9. Arnold, H. \& Maier, K.-P. (1971), Biochim. Biophys. Acta $251,133-140$.

10. Schimke, R. T.(1962), J. Biol. Chem. 237, 459-468.
11. Geriotti, C. (1970) in: Methoden der Enzymatischen Analyse (Bergmeyer, H. U, ed.) Vol. I, Verlag Chemie, Weinheim, p. 654-657.

12. Peraino, C. \& Pitot, H. C. (1963), Biochim. Biophys. Acta $73,222-231$.

13. Bode, C., Goebell, H. \& Strähler, E. (1968), diese Z. 6, 419-422.

14. Pette, D. (1968), in: Praktische Enzymologic (Schmidt, F. W. ed.), Huber-Verlag, Bern, p. 15-46.

15. Strecker, H. (1965), J. Biol. Chem. 240, 1225-1231.

16. Jones, M. E. \& Spector, L. (1960), J. Biol. Chem. 235, 2897-2892.

17. Mora, J., Martuscelli, J., Ortitz-Pineda, J. \& Soberon, G. (1965), Biochem. J. 96, 28-37.

18. Merker, H. J. (1969), Histochemie, 17, 83-89.

19. Amold, H. \& Maier, K.-P. (1972), Enzyme 13, 261-266.

20. Maier, K.-P., Volk, B., Hoppe-Seyler, G. \& Gerok, W. (1974), Europ. J. Clin. Invest. 4, 193-195.

21. Maier, K.-P. \& Pette, D. (1970), Clin. Chim. Acta, 29, 576-579.
Dr. K.-P. Maier Medizinische Universitätsklinik D-78 Freiburg i. Br. Hugstetterstraße 55 